\title{
Temporary vertebral flow reversal by Mono Mo.Ma: a new proximal protection system in the treatment of recent vertebral artery occlusion
}

Zastosowanie systemu proksymalnej protekcji mózgowej Mono Mo.MA w leczeniu świeżej niedrożności tętnicy kręgowej

\author{
Tadeusz Przewłocki, Piotr Pieniążek, Anna Kabłak-Ziembicka, Leszek Wrotniak, tukasz Tekieli, Piotr Podolec \\ Department of Cardiac and Vascular Diseases, Institute of Cardiology, Jagiellonian University, School of Medicine, The John Paul II Hospital, \\ Krakow, Poland
}

Post Kardiol Interw 2012; 8, 1 (27): 66-69 DOI: 10.5114 /pwki.2012.28072

\begin{abstract}
The major concern in performing percutaneous procedures for the treatment of vertebrobasilar obstructive disease is the risk of embolic phenomena. We describe the successful treatment of a symptomatic patient with bilateral vertebrobasilar disease utilizing a new proximal protection device, Mono Mo.Ma.
\end{abstract}

Key words: vertebral artery occlusion, Mono Mo.Ma device, drug-eluting stent, posterior circulation ischaemia

\section{Streszczenie}

Głównym ograniczeniem zabiegów przezskórnej rewaskularyzacji tętnic kręgowych jest zjawisko embolizacji okołozabiegowej do tętnic mózgowych zaopatrujących tylny krąg unaczynienia mózgu i ryzyko wystąpienia udaru mózgu. Opisano zabieg skutecznej rekanalizacji tętnicy kręgowej u chorego z obustronną niedrożnością tętnic kręgowych i objawami niedokrwienia mózgu z wykorzystaniem nowego systemu protekcji mózgowej Mono Mo.Ma i czasowym odwróceniem przepływu w tętnicy kręgowej.

Słowa kluczowe: niedrożność tętnicy kręgowej, system Mono Mo.Ma, stent uwalniający lek antyproliferacyjny, niedokrwienie tylnego kręgu unaczynienia mózgu

\section{Introduction}

Ischaemic strokes related to posterior fossa ischaemia (PFI) account for $25 \%$ of all transient ischemic attack (TIA) or ischaemic stokes, and they portend a mortality rate of 20-30\% [1]. As two vertebral arteries (VAs) usually supply blood to the posterior cerebral circulation, the loss of one is usually compensated by the sufficient antegrade flow in the other. Thus, ischaemic symptom occurrence is usually associated with bilateral occlusive VA disease or cerebral embolisation. In the vast majority of cases, when the cause is identified, a safe revascularisation procedure is questionable or impossible due to bilateral occlusion or the substantial risk of thrombus or plaque debris embolisation during the endovascular revascularisation procedure.

\section{Case report}

We present a case of a 69-year-old man with a 4-week history of posterior fossa ischaemia, with a left occipital ischaemic stroke due to bilateral VAs occlusion with recurrent headache, progression of visual disturbances, memory deficits and orientation problems.

Neurological examination revealed right-sided homonymous hemianopia and alexia (MMSE 18 points). Unenhanced head CT scan demonstrated left occipital lobe infarct without signs of haemorrhage.

Additionally, his medical history revealed ischaemic heart disease, arterial hypertension, hypertriglyceridaemia, diabetes mellitus, prior left renal artery stenting and chronic atrial fibrillation.

\section{Corresponding author/Adres do korespondencji:}

Tadeusz Przewłocki MD, PhD, Department of Cardiac and Vascular Diseases, Institute of Cardiology, Jagiellonian University, School of Medicine, The John Paul II Hospital, 80 Pradnicka, 31-202 Krakow, Poland, tel. +48 12614 22 87, fax: +48 12423 43 76, e-mail: tadeuszprzewlocki@op.pl Praca wpłynęła: 20.03.2012, przyjęta do druku: 31.03.2012. 
Three weeks after the first episode of cerebral ischaemia, the patient was transferred to our cardiology and vascular department for further assessment due to significant heart rhythm disturbances on Holter ECG monitoring in the presence of left ventricle contractile dysfunction, as a potential cause of intermittent neurological symptoms gradually arising during the last weeks.

In our department, duplex ultrasonography demonstrated non-significant carotid artery disease, and proximal occlusion of the right VA and near-occlusion of the left $\mathrm{VA}$, with bilateral collateral circulation from the thyrocervical trunk.

Echocardiography confirmed markedly reduced left ventricle ejection fraction to $35 \%$ with spontaneous echo contrast in left heart chambers, as well as mild mitral and aortic insufficiencies.

Coronary angiography demonstrated chronic proximal right coronary artery occlusion with good collateral flow from the non-obstructed branches of the left coronary artery. During the same session, selective VA arteriography confirmed ostial occlusion of the right VA (Figure 1) and ostial $8 \mathrm{~mm}$ long near-occlusion of the left VA, with significant collateral flow from the left thyrocervical trunk (Figure 2).

Taking into consideration the intermittent neurological symptoms, a consultant neurologist was asked to reassess the patient's status, and he diagnosed intermittent symptoms of posterior fossa ischaemia related to bilateral VA occlusive disease. Further patient management was discussed by the multidisciplinary team including a cardiologist, invasive cardiologist, vascular surgeon and neurologist, and in consequence the patient was referred for endovascular recanalisation of the left $V A$.

The patient was typically pre-treated with dual antiplatelet therapy (aspirin $75 \mathrm{mg} /$ day and clopidogrel $75 \mathrm{mg} /$ day). Vascular access was gained via the femoral approach. Considering the high risk of thrombus presence in the occluded portion of the artery, we decided to create a temporary stop flow in the subclavian artery (SA) to prevent possible cerebral embolisation and embolic stroke during catheter manipulations within the left VA.

We used a new variant of a proximal protection device system - Mono Mo.Ma Ultra (Medtronic Inc. Parkway, Minneapolis MN USA), dedicated to proximal protection during carotid stenting of the internal carotid artery (ICA) in the presence of ipsilateral external carotid artery occlusion.

After the Mono Mo.Ma cerebral protection device was placed in the proximal left SA, blood flow was arrested by expanding the device balloon (Figure $2 \mathrm{C}$ ). An attempt of typical recanalisation with a 0.014" Whispear (Abbott Vascular, Redwood City, CA, USA) coronary wire was unsuccessful due to insufficient support in the wide SA. After many attempts, we decided to use a 5 F Judkins Right 4.0, $125 \mathrm{~cm}$ length catheter (Cordis, Johnson\&Johnson Company, Miami Lakes, FL, USA) introduced through the main channel of the Mono Mo.Ma system device. The tip of this catheter was directed into the visible stump of the occluded left VA, providing good support for wire recanalization. The occlusion site of the left VA was crossed with a HT BMW 0.014" $300 \mathrm{~cm}$ wire (Abbott Vascular) (Figure $2 \mathrm{D}$ ). Then, the Judkins catheter was removed and pre-dilation with a rapid exchange Sprinter Legend 2.5/15 mm (Medtronic, Inc. Minneapolis, MN, USA) coronary balloon catheter was performed (Figure $2 \mathrm{E}$ ).

Immediately afterwards, reverse flow in the left VA was detected (Figure 2 F). A Resolute 3.0/18 mm (Medtronic) drug-eluting stent was implanted in the stenotic portion of the vessel with a typical stent protrusion to the SA. After stent deployment with $12 \mathrm{~atm}$, the balloon was partially withdrawn and ostial flaring with 16 atm was performed.

The whole stenting procedure was performed under the protection of iatrogenically inverted vertebral flow, which was confirmed angiographically (Figure $2 \mathrm{~F}$ ). Before deflation of the Mono Mo.Ma system, a typical aspiration with 2 syringes was performed. The final angiography showed proper stent deployment and optimal antegrade flow in the left VA (Figure $2 \mathrm{H}$ ). No periprocedural or postprocedural complications were observed. The patient was discharged from the hospital with recommendations of

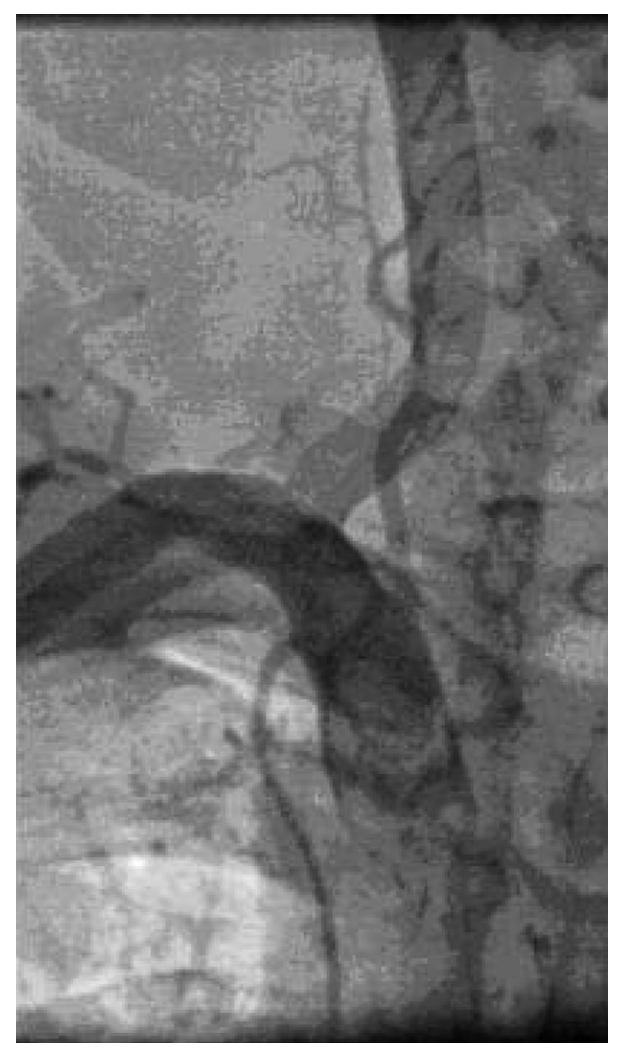

Fig. 1. Baseline selective angiography of the right subclavian artery showing occlusion of the right vertebral artery

Ryc. 1. Angiografia prawej tętnicy podobojczykowej - niedrożność prawej tętnicy kręgowej 


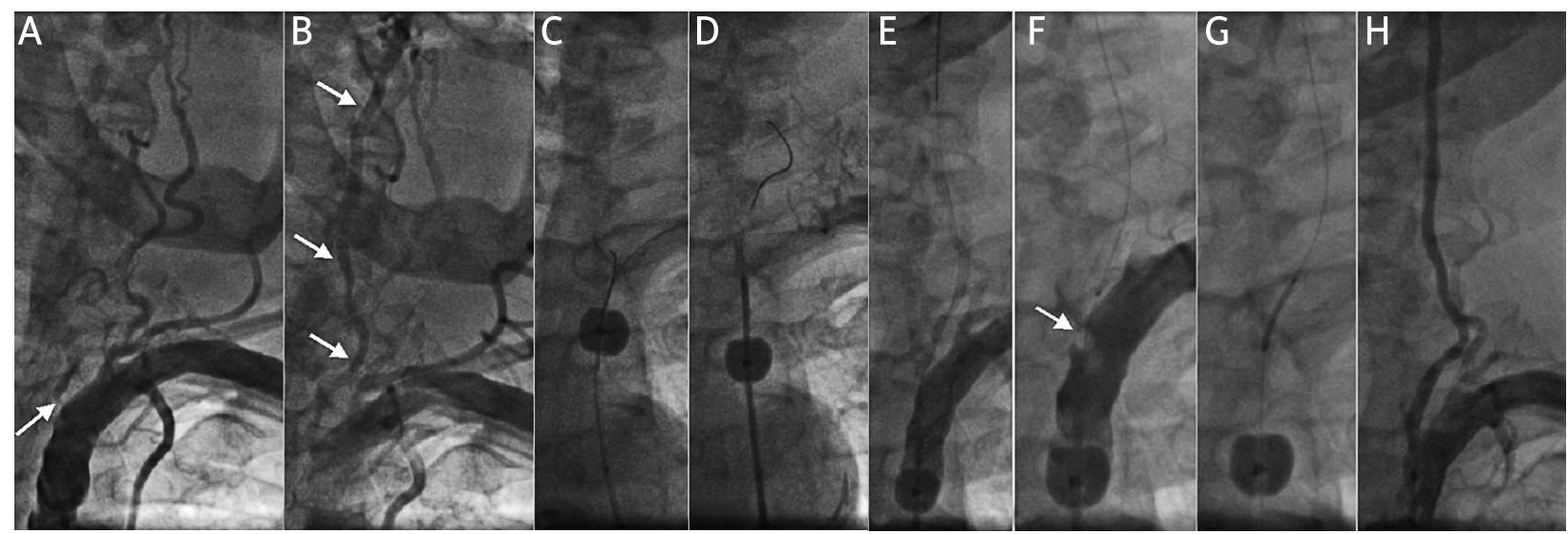

Fig. 2. A - Baseline selective angiography in an early phase of contrast agent administration of the LVA showing near occlusion of the ostium (arrow). B - Late image frames showing LVA filling from the collateral flow (arrows). C - Mono Mo.Ma emboli protection device in the proximal portion of the left subclavian artery. D - Successful crossing of the occlusion site with a HT BMW 0.014 " $300 \mathrm{~cm}$ wire. E - LVA after pre-dilation with a rapid exchange Sprinter Legend 2.5/15 mm coronary balloon catheter. F - Visible flow reversal from LVA to the left subclavian artery. $\mathrm{G}$ - Stent in position prior to deployment. $\mathrm{H}$ - Final angiographic result of the LVA stenting Ryc. 2. Angiografia lewej tętnicy podobojczykowej. A - wczesna faza podania kontrastu - subtotalne zwężenie lewej tętnicy kręgowej, B - późna faza podania środka cieniującego - wypetnianie tętnicy kręgowej poprzez krążenie oboczne, $C$ - balon systemu Mono Mo.Ma rozprężony w proksymalnym odcinku tętnicy podobojczykowej, $D$ - sforsowanie niedrożności prowadnikiem HT BMW 0,014, $300 \mathrm{~cm}, E$ - LVA po predylatacji balonem Sprinter Legend 2,5/15 mm, F-widoczne ujemne kontrastowanie tętnicy podobojczykowej wywołane odwróceniem przeptywu w LVA, G-pozycjonowanie stentu w LVA, $\mathrm{H}$-obraz LVA po implantacji DES i deflacji systemu protekcji

dual antiplatelet therapy for at least 12 months, statin, proton pump inhibitor, calcium channel blocker, ACE inhibitor, torasemide, and spironolactone.

The post-procedure neurological assessment demonstrated symptom resolution, with only mild visual loss.

\section{Discussion}

The use of protection systems during VA procedures is not routinely recommended, as opposed to ICA stenting. Studies employing transcranial Doppler and diffusionweighted magnetic resonance imaging (MRI) have documented microembolization during interventional procedures [2-4]. Furthermore, the frequency and amount of captured emboli during stent procedures in ICA and ostial VAs seem comparable $[5,6]$. However, when protection is used, most authors use distal protection systems, particularly in the presence of VA lesions containing thrombus or very soft and ulcerated plaques $[7,8]$.

We have previously described a case of impending stroke with marked symptoms of posterior fossa ischaemia due to floating thrombus in the left VA origin, successfully treated with angioplasty, where flow reversal in the left VA was achieved with a guiding catheter of the Flow Reversal Gore Neuroprotection System (W.L. Gore\&Associates, Flagstaff, AZ, USA) [9]. This technique was also successfully used in several cases of high-risk SA lesions involving origin of the VA $[10,11]$. In high-risk SA stenting requiring covering of the VA origin, proximal protection is the only one to be employed as a filter device could not be removed from the VA after stent implantation to the SA.

Proximal protection through flow reversal creation in the VA seems to be very desirable in terms of patient safety. The only risk of this technique is upper limb artery embolisation by debris washed out from the VA by the reverse flow. However, due to rich collaterals in palmar arch arteries, the risk of upper limb ischaemia is rather negligible.

This novel Mono Mo.Ma system dedicated to ICA stenting in the presence of ipsilateral external carotid artery occlusion has $8 \mathrm{~F}$ size, whereas GORE NPS is substantially bigger and bulkier (10 F). Thus, in cases of very high-risk VA and/or SA angioplasty, Mono Mo.Ma system protection seems reasonable and it may be recommended.

The other aspect worth considering is the use of drugeluting stents for VA stenosis. As the restenosis rate after VA balloon angioplasty or coronary bare-metal stent placement is remarkably high (up to $50 \%$ ), it constitutes a severe drawback of VA endovascular procedures [12-14]. Recent reports have suggested decreased restenosis rates with drug-eluting stents to $7-8.5 \%$ at 12 months and $17 \%$ at 21 months, as compared to $23.1 \%$ and $38 \%$ respectively, in patients who received bare metal stents [15-17]. Taking into consideration these data, in the presented patient, we applied a drug-eluting stent, despite the lack of guide- 
lines concerning this issue. The drawback of drug-eluting stents may be a need of prolonged dual antiplatelet therapy. However, the duration of such treatment is extrapolated from data available from the coronary field, due to completely missing data concerning timing of dual antiplatelet therapy after VA stenting.

In conclusion, it seems that the proximal protection device Mono Mo.Ma can be used safely and effectively in high-risk angioplasty of the VA.

\section{References}

1. Lee CJ, Morasch MD. Treatment of vertebral disease: appropriate use of open and endovascular techniques. Semin Vasc Surg 2011; 24: 24-30.

2. Kablak-Ziembicka A, Przewłocki T. Carotid artery stenting drawbacks: microembolic ischemic cerebral lesions - so they matter? J Endovasc Ther 2011; 18: 527-530.

3. Jeong HS, Song HJ, Lee JH, et al. Interpretation of TCD spectral patterns detected during carotid artery stent interventions. J Endovasc Ther 2011; 18: 518-526.

4. Kablak-Ziembicka A, Przewlocki T, Pieniazek P, et al. Assessment of flow changes in the circle of Willis after stenting for severe internal carotid artery stenosis. J Endovasc Ther 2006; 13: 205-213.

5. Divani AA, Berezina TL, Zhou J, et al. Microscopic and macroscopic evaluation of emboli captured during angioplasty and stent procedures in extracranial vertebral and internal carotid arteries. J Endovasc Ther 2008; 15: 263-269.

6. Qureshi Al, Kirmani JF, Harris-Lane P, et al. Vertebral artery orogin stent placement with distal protection: technical and clinical results. Am J Neuroradiol 2006; 27: 1140-1145.

7. Amole AO, Akdol MS, Wood CE, et al. Endovascular management of symptomatic vertebral artery origin stenosis in the presence of an acute thrombus. J Neurointerv Surg 2011 [Epub ahead of print].

8. Mintz EP, Gruberg L, Kouperberg E, Beyar R. Vertebral artery stenting using distal emboli protection and transcranial Doppler. Catheter Cardiovasc Interv 2004; 61: 12-15.

9. Pieniazek P, Musialek P, Motyl R, et al. Use of the Parodi AntiEmboli System and transient subclavian steal for cerebral protection during emergent vertebral artery recanalization. J Endovasc Ther 2004; 11: 511-516.

10. Przewlocki T, Kablak-Ziembicka A, Pieniazek P, et al. Determinants of immediate and long-term results of subclavian and innominate artery angioplasty. Catheter Cardiovasc Interv 2006; 67: 519-526.

11. Przewlocki T, Kablak-Ziembicka A, Pieniazek P, et al. Predictors of restenosis in patients treated with angioplasty for subclavian artery occlusive disease. Post Kardiol Interw 2009; 5: 113-122.

12. Ko YG, Park S, Kim JY, et al. Percutaneous interventional treatment of extracranial vertebral artery stenosis with coronary stents. Yonsei Med J 2004; 45: 629-634.

13. SSYLVIA Study Investigators. Stenting of Symptomatic Atherosclerotic Lesions in the Vertebral or Intracranial Arteries (SSYLVIA): study results. Stroke 2004; 35: 1388-1392.

14. Coward LJ, Featherstone RL, Brown MM. Percutaneous transluminal angioplasty and stenting for vertebral artery stenosis. Cochrane Database Syst Rev 2005; 2: CD000516.

15. Gupta R, Al-Ali F, Thomas AJ, et al. Safety, feasibility, and shortterm follow-up of drug-eluting stent placement in the intracranial and extracranial circulation. Stroke 2006; 37: 2562-2566.
16. Paluszek P, Pieniążek $P$, Musiałek $P$, et al. Symptomatic vertebral artery stenting with the use of bare metal and drug eluting stents. Post Kardiol Interw 2009; 5: 1-6.

17. Ogilvy CS, Yang X, Natarajan SK, et al. Restenosis rates following vertebral artery origin stenting: does stent type make a difference? J Invasive Cardiol 2010; 22: 119-124. 